\title{
Assessment Of Commercial Bottled Table And Sachet Water Commonly Consumed In Federal University Of Technology, Owerri (FUTO), Imo State, Nigeria Using Microbiological Indices.
}

\author{
H.C.C. Maduka ${ }^{1}$, N.C. Chukwu ${ }^{1}$, C.E. $\mathrm{Ugwu}^{2}$, C.C. Dike ${ }^{2}$, A.N.Okpogba ${ }^{2}$, P.N. \\ Ogueche $^{2}$, A.A. Maduka ${ }^{3}$ \\ ${ }^{1}$ Department of Biochemistry, Federal University of Technology, Owerri (FUTO), Imo State, Nigeria. \\ ${ }^{2}$ Department of Human Biochemistry, Faculty of Basic Medical Sciences, College of Health Sciences, Nnamdi \\ Azikiwe University,PMB.5001,Nnewi, Anambra State, Nigeria.Pin:3610 \\ ${ }^{3}$ Depatment of Gender Studies, the University of Hull, HU6, 7RK, UK.
}

\begin{abstract}
This study investigated the safety and portability of some notable bottled and sachet table water sold and consumed in Federal University of Technology-Owerri (FUTO), Imo State, Nigeria using common bacterial contaminants as index of indicators of water quality. Seven different bottled water samples obtained from different manufacturers labeled $A_{1}$ to $A_{7}$ and seven different sachet water samples also from different manufacturers labeled $B_{1}$ to $B_{7}$ were analyzed microbiologically and physically.Physical examinations of the samples showed they were colourless with no offensive odours.Escherichia coli(E.coli),Streptococcus faecalis, Klebsiella pneumoniae,Staphylococcus aureus and Salmonella typhmurium were tested .Bottled water samples $A_{1}, A_{2}, A_{3}, A_{6}$ and $A_{7}$ as well as sachet water samples $B_{1}, B_{2}$, and $B_{7}$ had bacteria count per $100 \mathrm{ml}(\mathrm{MPN} / 100 \mathrm{ml})$ at $37^{\circ} C$ while bottled water samples $A 4$ and as well as sachet water samples $B_{3}, B_{4}, B_{5}$ and $B_{6}$ had less than 10 coliform count per $100 \mathrm{ml}(\mathrm{MPN} / 100 \mathrm{ml})$ at $44^{\circ} \mathrm{C}$.The test samples $A_{1}, A_{2}, A_{3}, A_{6}$ and $A_{7}$ and sachet water samples $B_{1}, B_{2}$, and $B_{7}$ belonged to excellent category $(A)$ while samples $A_{4}$ and $A_{5}, B_{3}, B_{4}, B_{5}$ and $B_{6}$ belonged to satisfactory category(B). 21.43 \% E.coli,7.14\% Sreptococcus face alis,7.14\% Klebsiella pneumoniae and $14.29 \%$ Staphylococcus aureus were found in only bottled table water samples $A_{4}$ and $A_{5}$ respectively while in sachet water samples, the prevalence of other bacteria was $42.43 \%$ for E. coli in samples B3,B4, B5 and B6,24.24\% for Streptococcus faecalis in samples B3, B4, B5 and B6, while the $12.12 \%$ Klebsiella pneumoniae in samples B3, B4, B5 and B6, while the 21.21 \% Staphylococcus aureus was present in samples B3, B4, B5 and B6 respectively.
\end{abstract}

Key words: Bacteria counts, Commercial table water and Microbiological indices.

\section{Introduction}

In many developing countries, availability of water has become a critical and urgent problem and it is a matter of great concern to families and communities [1].Increase in human population has exerted an enormous pressure on the provision of safe drinking water especially in developing countries [2 ].Unsafe water is a global public health threat, placing persons at risk for a host of diarrhea and other diseases as well as chemical intoxication [3]. Unsafe water is a worldwide public health threat endangering people to diarrhea and other diseases as well as intoxication of chemical [4]. Each year, over two million persons, mostly children less than 5 years of age, die of diarrhea disease [5]. For children between this age group, diarrhea disease accounted for 17 $\%$ of all death from 2000 to 2003[6].

Escherichia coli is the most preferred faecal coliform used in assaying water analysis because it gives indication of faecal contamination [7]. Industrial and agricultural chemicals leached from the land, enter water in a great amount and they could be resistant to biodegradation. Apart from this, rural water often have excessive amount of nitrite from microbial action on agricultural fertilizers [8].To supply safe water to various communities, an understanding of water that is microbiologically and chemically certified is therefore necessary. The Nigeria based National Agency for Food and Drugs Administration Control(NAFDAC) in association with the World Health Organization(WHO), recommended that potable water for consumption should not contain any microorganism that is known to be pathogenic and the coliform number per $100 \mathrm{ml}$ of water must be zero[6].

The bacteriological quality of drinking water is of paramount importance and monitoring must be given highest priority. This is so because studies have attributed several disease outbreaks to untreated or poorly treated water containing bacteria pathogens that have been isolated from sachet water [9 ]. Hence, the aim of this work is to assess the quality of commercial bottled table and sachet water commonly consumed in Federal 
University of Technology Owerri(FUTO), Nigeria, in order to ascertain whether they are safe for human consumption.

\subsection{Source of Samples}

\section{Materials and methods}

Seven different samples each of bottled table water and sachet table water were purchased from the shops inside or within FUTO. Each sample was dispensed into cleanly labelled sample bottles and used for various microbiological analyses. The bottled table water were labeled $A_{1}$ to $A_{7}$ while the sachet water samples were labeled $\mathrm{B}_{1}$ to $\mathrm{B}_{7}$

\subsection{Microbial screening}

This was carried out by inoculating freshly prepared media with the water samples and incubated at 37 ${ }^{0} \mathrm{C}$ for $24 \mathrm{~h}$ and checked for any microbiological growth.

\subsubsection{Spread plate method}

The colony count was done using the spread plate method of [10]. This was done by inoculating $0.5 \mathrm{ml}$ of diluted bacteria suspension over the surface of dry solid medium using a sterile spreader. The plate was incubated upside down. The colonies that appear on the agar surface were counted and the number of bacteria per ml estimated.

\subsection{Materials used}

These were water samples (bottled table water labeled $A_{1}-A_{7}$ and sachet table labeled $B_{1}-B_{7}$ water), sterile test tubes, ringer solution, $10 \mathrm{ml}$ pipette, Mackonkey broth containing bromocresol purple indicator(double strength) with inverted Durham tube Mackonkey broth containing bromocresol purple indicator(single strength)with inverted Durham tube, sterile cotton wool, wire loop and autoclave

\section{Results}

The results of the bottled table water and sachet table water which were subjected to microbiological screening for the common bacterial contaminants of drinking water were shown in tables 1-4. The most probable number (MPN) was detected in samples $\mathrm{A}_{4}$ and $\mathrm{A}_{5}$ to be 1.0, 1.0(table 1). The MPN for the other samples, $A_{1}, A 2, A_{3}, A_{6}$ and $A_{7}$ was 0 . The $\%$ bacterial counts for bottled table water $A_{1}$ to $A_{7}$ were, $21.43 \%$, $7.14 \%, 7.14 \%, 14.29 \%, 0 \%$, for E. coli,Streptococcus faecalis, Klebsiella pneumonia, Staphylococcus aureus and Salmonella typhmurium( table 2). The MPN for sachet water samples $\mathrm{B}_{1}$ to $\mathrm{B}_{7}$ were, $0,0,2,1,1,2,0$ (see table 3), while the \% bacteria count were $42.42 \%, 24.24 \%, 12.12 \% 21.21 \%$ and $0 \%$ for E. coli, Streptococcus faecalis, Klebsiella pneumonia, Staphylococcus aureus and Salmonella typhmurium(table 4). E.coli had the highest bacteria count among all the bacteria species screened (tables 2 and 4). Samples B1, B2, and B7 were without any bacteria detected suggesting they are pure for consumption. Salmonella typhmurium was absent in all the samples. Results suggest that though the sachet water samples may not cause typhoid fever, there should be caution in their use because of the other pathogenic bacteria species detected.Results suggest that the table bottled water samples were and safer than the sachet(pure) water samples.

\section{Discussion}

Drinking water must be free from harmful microorganisms that can cause serious ill health[1].It was observed that the mean most probable number of faecal coliforms(MPN)/100ml of the seven bottled table water samples analyzed were found to fall within the excellent category. This is similar to the works of [11], [7], [4]. The absence of Salmonella typhmurium in all the samples suggests that typhoid fever may not be contracted from the water samples[12]. Bottled table water samples $A_{1}, A_{2}, A_{3}, A_{6}$, and $A_{7}$ had no coliform count per $100 \mathrm{ml}$, while $\mathrm{A} 4$ and $\mathrm{A}_{5}$ have less than 10 coliform count per $100 \mathrm{ml}$. This also suggests that the samples $\mathrm{A}_{1}, \mathrm{~A}_{2}$, $\mathrm{A}_{3}, \mathrm{~A}_{6}$ and $\mathrm{A}_{7}$ were not contaminated., coliform count more than 10 coliform count per $100 \mathrm{ml}$ is classified as "unacceptable" and unfit for drinking. [6], [13,and [14].However, the slight presence of E.coli which was discovered in bottled table water samples $\mathrm{A}_{4}$ and $\mathrm{A}_{5}$ signified that the above two samples $\mathrm{A}_{4}$ and $\mathrm{A}_{5}$ were contaminated and therefore not safe for human consumption. This is inline with the similar works reported by [11] and [4]. The presence of $E$. coli in a water sample is an indication of water pollution[2], [1].

The presence of E.coli is most often accompanied by the presence of dangerous enteric pathogens like Shigella, Salmonella and Campylobacter species[14], [15]. The World Health Organization(WHO) recognizes the fact that in many villages and small towns, it is not easy to supply regular water with an E.coli of zero per 100ml. So, for chlorinated water, $90 \%$ of samples analysed within one year should have a zero E.coli count per $100 \mathrm{ml}$ but in case of contamination, it should not exceed 5 E.coli count per $100 \mathrm{ml}$ otherwise investigation should be made on equipment, water system and the cause of contamination rectified[7]. Apart from E.coli isolated in 
sachet water samples, $\mathrm{B}_{3}, \mathrm{~B}_{4}, \mathrm{~B}_{5}, \mathrm{~B}_{6}$ and bottled table water samples, $\mathrm{A}_{4}$ and $\mathrm{A}_{5}$, organisms like Klebsiella pneumonia, Streptococcus faecalis and Staphylococcus aureus were also isolated and this finding is supported by those of some researchers who reported that accompanying presence of Klebsiella pneumonia, Streptococcus faecalis and Staphylococcus aureus with E.coli confirmed the pollution to be of faecal origin[13], [12]. [16], reported that well water is contaminated with heavy metals and some anions. The heavy metals include cadmium, chromium, lead, copper, iron, aluminium, manganese, zinc, magnesium and calcium, while the anions are fluoride, sulphate, chloride and nitrate. It has been reported that drinking of unhygienic water in poor countries has resulted in the death of 2.2 million people per annum, $99 \%$ of these are children under the age of five[17].

Furthermore, it has been discovered that many African countries lack safe drinking water. Only $46 \%$ of Africa's population has access to safe drinking water, while only $8 \%$ of Asia's population has acess to safe drinking water[18],[7].

\subsection{Conclusion}

The presence of bacteria in this study might be as a result of improper handling, processing, purification procedures, and unhygienic handling after production. Water with such bacteria are not safe for human consumption, hence the water source should be re-examined. All water that fails NAFDAC and WHO regulations should be retreated before they are released to the public for human consumption. Also, NAFDAC should intensify effort on batch number, production date and expiry date of all these samples vended in public. While most of the samples were of excellent categories and others in good satisfactory states, there is the need to be cautious in the consumption of sachet water samples suggesting that the manufacturers still need to improve on their manufacturing process and hygiene.

\section{References}

[1] L.V.Adekunle, M.K.C.,Sridhar, A.A. Ajayi, P.A. Oluwude, and J.F.Olawuyi. An assessment of the health and social economic implications of sachet water in Ibadan,Nigeria: A public health challenge.Afr. J. Biomed. Res. 7:5-8. June 2004

[2] M.O.Edema, A.M. Omemu and O.M.Fapetu.Microbiological and physiological analysis of different sources of drinking water in Abeokuta, Nigeria. J. Microbiol. 15(1):57-61. May 2001.

[3] O.A. Ashaye, A.A.Couple, O.O. Afolabi and S.B. Fasoyiro. Physicochemical properties of pure water samples in South Western Nigeria. J. Food Technol. Afr. 4:119-120. May 2001.

[4] I.O. Okonkwo, O.D. Adejoye, T.A. Ogunusi, E.A. Fajobi and O.B. Shittu Microbiological and physiochemical analysis of different water samples used for domestic purposes in Abeokuta and Ojota, Lagos State, Nigeria. Afr. J.Biotechnol. 7(3): 617-621. Jan 2008.

[5] J.M. Hughs and J.P Koplan(). Saving lives through global safe water. J. Emerging Infect. Dis. 11(10):1636-1637 Nov 2005.

[6] WHO.Guideline for water quality volume 1, H.M.S.O. Publication London. Pp. 6-9. ,Feb 1984.

[7] I.P. Ezeugwunne, N.R. Agbakoba, N.K. Nnamah and I.C. Anahalu. The prevalence of bacteria in packaged sachet water sold in Nnewi, South East, and Nigeria. World J. of Dairy and Food Sc. 4(1):19-21. June 2009.

[8] T.S. Steiner, N.M. Thielman and Guerrant, R.L.(1997). Protozoan agent, what are the dangers for public water supply? Ann. Rev. Med. 48:329-340.

[9] P. Shear, M.A. Hussein, A.H. Chowdhury and K.Z. Mamun .Water sources and environmental transmission of multiple resistant enteric bacteria in rural Bangladesh. 89(3):297-303. August 1995.

[10] M. Chessbrough. Laboratory manual for tropical countries. $3^{\text {rd }}$ ed. Tropical Health Tech., Butterworth, London. Pp. $220-235$ Apr 2001.

[11] I.C., Oladipo, I.C. Onyenike and A.O. Adebiyi. Microbiological analysis of some vended sachet water in Ogbomoso, Nigeria. Afr. J. of Food Sc. 3(12):406-412. Apr 2009.

[12] J.G. Tortora, R.B. Funke and L.C.Case. Microbiology an introduction. Media update of 7 edn. Including bibliography and index publisher. Daryl Fox. Pp. 258-260. June 2002

[13] Health Canada.Guidelines for Canada drinking water quality:Bacteria water-borne pathogens. Healthy environments and Consumer Safety Branch, Health Canada, Otta,Ontario.May 2006a.

[14] I.A. Shilklomanov. Appraisal and assessment of world water resources. Water Intl. 25(1):11-32. Sept 2000.

[15] S.C. Edberg. E.W. Rice, R.J Kar and M.J.Allen.Eschericha coli. The best biological drinking water indicator for public health protection. J. App. Microbiol. 88:1068-1168 .Jan 2000

[16] C. U. Victor, E. I. Akubugwo and F. O. Uhegbu.. Biochemical impact of selected well water sources at Ishiagu on liver and Technology 2(7):52-55. Nov 2012.

[17] WHO. Guidelines II for drinking water quality, volume 1. EFP/82.39. WHO,(2) Geneva 27, Switzerland. July 2004.

[18] A.C.Dada .Sachet water phenomenon in Nigeria: Assessment of the potential health impacts. Afr. J. Microbiol. Res. 1:15-21 May 2009.

Table 1: The most probable number (MPN) of the bottled table water samples

$\begin{array}{cllc}\text { Bottled table water } & \mathbf{1 0 m l} & \mathbf{1 m l} & \text { MPN/100 } \\ \mathrm{A}_{1} & 0 & 0 & 0 \\ \mathrm{~A}_{2} & 0 & 0 & 0 \\ \mathrm{~A}_{3} & 0 & 0 & 0 \\ \mathrm{~A}_{4} & 1 & 0 & 1.0 \\ \mathrm{~A}_{5} & 1 & 0 & 1.0 \\ \mathrm{~A}_{6} & 0 & 0 & 0 \\ \mathrm{~A}_{7} & 0 & 0 & 0\end{array}$


Table 2: Microbial screening of the bottled table water samples

Bacteria species \% Bacteria count

Eschericha coli

Streptococcus faecalis

Klebsiella pneumonia

Staphylococcus aureus

Salmonella typhmurium

$\begin{array}{lll} & \text { A1 } & \text { A2 } \\ 21.43 & 0 & 0 \\ 7.14 & 0 & 0 \\ 7.14 & 0 & 0 \\ 14.29 & 0 & 0 \\ 0 & 0 & 0\end{array}$

$\begin{array}{lllll}\text { A3 } & \text { A4 } & \text { A5 } & \text { A6 } & \text { A7 } \\ 0 & 0 & 4 & 0 & 0 \\ 1 & 0 & 1 & 0 & 0 \\ 1 & 0 & 1 & 0 & 0 \\ 1 & 0 & 1 & 0 & 0 \\ 0 & 0 & 0 & 0 & 0\end{array}$

Table3: The most probable number (MPN) of the sachet table water samples Sachet table water

$\mathrm{B}_{1}$ 10ml $1 \mathrm{ml} \quad \mathrm{MPN} / \mathbf{1 0 0}$

$\mathrm{B}_{2}$

$\mathrm{B}_{3}$

$\mathrm{B}_{4}$

$\mathrm{B}_{5}$

$\mathrm{B}_{6}$

$\mathrm{B}_{7}$

$\begin{array}{lll}0 & 0 & 0 \\ 0 & 0 & 0 \\ 1 & 1 & 2 \\ 1 & 0 & 1 \\ 1 & 0 & 1 \\ 1 & 1 & 2 \\ 0 & 0 & 0\end{array}$

Table 4: Microbial screening of the different sachet table water samples

$\begin{array}{lclllllll}\text { Bacteria species } & \% \text { Bacteria count B1 } & \text { B2 } & \text { B3 } & \text { B4 } & \text { B5 } & \text { B6 } & \text { B7 } \\ \text { Escherichia coli } & 42.42 & 0 & 0 & 4 & 6 & 3 & 1 & 0 \\ \text { Streptococcus faecalis } & 24.24 & 0 & 0 & 1 & 3 & 1 & 3 & 0 \\ \text { Klebsiella pneumonia } & 12.12 & 0 & 0 & 1 & 1 & 1 & 1 & 0 \\ \text { Staphylococcus aureus } & 21.21 & 0 & 0 & 3 & 1 & 2 & 1 & 0 \\ \text { Salmonella typhmurium } & 0 & 0 & 0 & 0 & 0 & 0 & 0 & 0\end{array}$

